\title{
電気泳動による混合微粒子の分離
}

\author{
山東 睦 夫*, 砥 綿 篤 哉*, 上 㝨 義 則*, 桑 原 好 孝*
}

\section{The Separation of Mixed Fine Powders by Electrophoresis}

by

\author{
Mutsuo SANDO $^{\dagger}$, Atsuya TOWATA ${ }^{\dagger}$, Yoshinori UWAMINO ${ }^{\dagger}$, \\ and Yoshitaka KUWAHARA ${ }^{\dagger}$
}

\begin{abstract}
A sub-micron powder of either alumina or zirconia was separated by electrophoresis. A mixed suspension of these powders was prepared in a powder concentration of $150 \sim 200 \mathrm{ppm}$ at $\mathrm{pH} 5.0$, where both alumina and zirconia had enough positive zeta potential to prevent from their heterocoagulation. A uniform and stable ascent flow of electrolytic solution at pH 7.4 was made, where the difference of zeta potential between alumina and zirconia was about the maximum. The ascent flow carried a fine stream of the suspension with a diameter of less than $1 \mathrm{~mm}$. Applying an electric field of $10 \mathrm{~V} / \mathrm{cm}$ perpendicular to the flow, the fine stream of suspension was divided into two fine streams. The concentration of different kind particles in each separated suspension was reduced to $1 / 10$ of that in original mixed suspension.
\end{abstract}

Key Words : Separation, Electrophoresis, Zeta Potential, Sub-micron Powder, Alumina, Zirconia

\section{1. はじめに}

サブミクロン領域の表面被覆型あるいは表面改質型 の複合粒子は, 粒子表面の化学的特性を大きく変化さ せることができるため, 分散強化用フィラ一, 顔料あ るいはセラミクス原料といった分野において使用が 拡大しつつある。しかしながら，それらの粒子の表面 改質状態の評価には, 粒子表面の化学的特性の変化が ほとんど利用されておらず, 電子顕微鏡による一部の 粒子の観察, 複合粒子の 電位特性といった平均值的測 定，あるいは塗料・プラスチックとの混練品の耐久性 の変化といった間接的手法により評価が行われてい

\section{3年 8月 31日 受付}

粉体工学会第29回夏期シンポジウム(1993年 7月, 函南)にて発表

* 名古屋工業技術研究所セラミックス基礎部

( ( 462 名古屋市北区平手町 $1-1$ )

TEL. 052-911-2111 内線 573

$\dagger$ National Industrial Res. Inst. of Nagoya

(Hirate-cho, Kita-ku, Nagoya 462)
る。また, 現状においては, サブミクロン域の表面改 質粒子からの未改質粒子の分離法はほとんど考慮され ていない。

表面改質粉体と未改質粉体の混合物は, 表面の化学的 特性のみから考えると, 組成の異なる粉体の混合物と 同じであり, 多成分混合粉体の分離法を適用して表面 改質状態を評価することができると考えられる。比重 選別, 浮遊選別等のよく知られた分離法 ${ }^{1}{ }^{1}$ は, 水溶液中 における沈降速度が大きい数更以上小粒子に主に適 用されるものであるため, サブミクロン領域の混合粉 体の分離に適用することは困難である。

ここでは，異なったら電位- $\mathrm{pH}$ 特性を持つサブミ クロン粒子の混合物の分離の基礎研究として, 生体化 合物の分離法として主に用いられている電気泳動 ${ }^{2)}$ 応用した装置を用いて, 二成分混合粉体の分離を試み た。 


\section{2. 分離の原理}

水溶液中において電場 $E$ を受け, ゼー夕電位 つ粒子は, 速度 $u$ で電気泳動する。

$$
u=\frac{\varepsilon}{\pi \eta} f E \zeta
$$

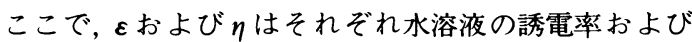
粘性率, $f$ は電気泳動遅延効果係数である。

係数 $f$ は, 電気泳動に伴う緩和効果を無視した場合, 水溶液のデバイ長さの逆数 $\kappa$ と粒子半径 $a$ の積の単調 な関数となり, $\kappa a<<1 の$ とき $1 / 6, \kappa a>>1$ のとき $1 / 4$ となる ${ }^{3)}$ 。なお, Wiersema $5^{4)}$ の理論計算による と, 緩和効果の影響は粒子の $\zeta$ 電位が $100 \mathrm{mV}$ 程度以上 になった場合に顕著となる。このため, 電位の值が 数 $10 \mathrm{mV}$ の粒子では, 粒子の粒度分布が大きいとして も, 泳動速度は最大1.5倍しか異ならない。

電気泳動以外の水溶液中における粒子の移動の原因 として, 荷電粒子どうしのクーロン力, 水溶液自身の 流れおよび粒子のブラウン運動による拡散が考えら れる。これらの移動を無視できる場合, 混合された粉 体が水溶液中でそれぞれ持つ電位の值の比が 1.5 以上 となれば, 混合された粉体を分離できることになる。

\section{3. 実 験}

\section{1 分離装置}

分離装置の概略図をFig. 1に示す。無脈流ポンプを 用いて, $\mathrm{pH}$ 值と電気伝導率を調整した電解質水溶液 6.5 65ml / minをキャリアとして装置下部から送り 込むことにより，白金製電極に挟まれた流路内に上向

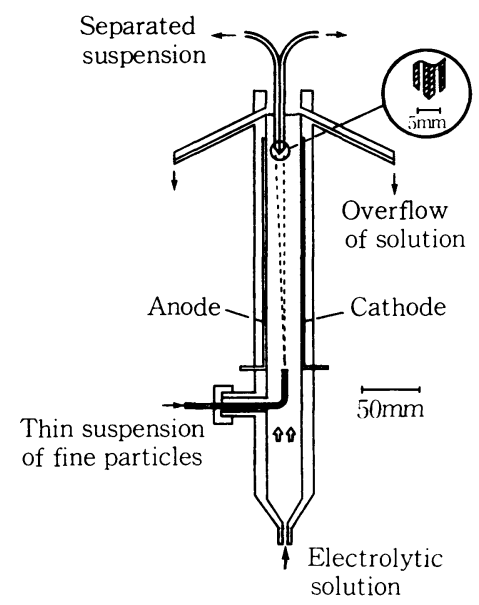

Fig. 1 Schema of separator by electrophoresis

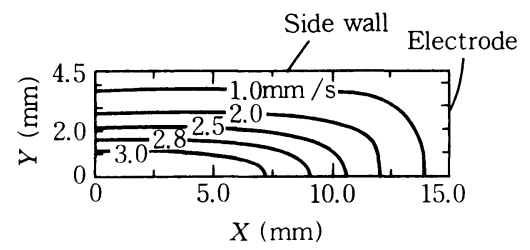

Fig. 2 Pattern of ascent flow speed in rectangular path. Flow speed at center of the path $(0,0)$ is 3.2 $\mathrm{mm} / \mathrm{s}$

きの流れを作った。電極の極間距離は30mmであり, 電極の流れ方向の長さは200mmである。また, 図に垂 直な方向の流路の奥行きを約 $9 \mathrm{~mm}$ とした。矩形流路 $(30 \times 9 \mathrm{~mm})$ を通る水溶液の流量を, $30.3 \mathrm{l} / \mathrm{min}$ として 計算した定常状態の上向きの流速分布をFig. 2 に示 す。流路中央 $(0,0)$ の流速は $3.2 \mathrm{~mm} / \mathrm{s}$ であり, 流路の 中央部およそ $16 \times 3 \mathrm{~mm}$ の棈円の範囲内において, 流速 の変化が $10 \%$ 以下の一様な流れが得られる。

混合粉体の希薄な愁濁液 $0.2 \sim 1.0 \mathrm{ml} / \mathrm{min}$, チュ 一ブポンプにより水溶液の流れの下部中央に設置した ガラ又管(外径約 $1.0 \mathrm{~mm}$, 内径約 $0.4 \mathrm{~mm}$ ) へ送り込み, 希薄愻濁液の直径 $1 \mathrm{~mm}$ 以下の細流としてキャリア水 溶液の流れに乗せた。電気泳動用の電極の間を通過し た水溶液は, 装置上部で左右に分流させて落下させ た。なお, 希薄㦟濁液の細流は, 装置上部の分流部によ る流れの乱れの影響を受けない部分において, 図に示 した 2 本のチューブを通してそれぞれ $0.5 \sim 3.0 \mathrm{ml}$ $/ \min$ 速さで吸引した。

\section{2 粉体稔濁液の調製}

混合粉体の成分として, 簡単のため, 特性の明かな 高純度 $\alpha^{-}$アルミナ(大明化学製タイミクロンTM-DA, 粒径約 $0.1 \mu \mathrm{m}$ ) と高純度単斜晶ジルコニア(東洋ソーダ 製ジルコニア TZ-0, 粒径約 $0.05 \mu \mathrm{m}$ )を使用した。こ れらの粉体の表面污染を除くため, 先ず空気中 $500{ }^{\circ} \mathrm{C} て$ 加熱し, さらに蒸留水により十分に洗浄した。電気泳 動レーザドプラ 電位計(Pen Kem 製 SYSTEM 3000）を用いて測定した粉体の 電位 $\mathrm{pH}$ 特性を Fig. 3に示す。アルミナ及びジルコニアの等電点は, それ

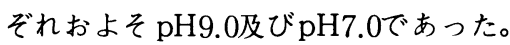

アルミナとジルコニアが互いにへテロ凝集せず, $\zeta$ 電位が十分大きく良好な分散性を示す $\mathrm{pH} 5.0$ において, 水 $100 \mathrm{ml}$ あたり粉体が $15 〜 20 \mathrm{mg}$ 含まれる希薄的濁液 とし、これらを等量づつ混合することにより二成分混 合粉体の眸濁液とした。なお，電導度計（東亜電波工業 製CM-11P)により測定した混合粉体希薄愁濁液の電導 度は,おおよそ $12 \mu \mathrm{S} / \mathrm{cm}\left(25^{\circ} \mathrm{C}\right)$ であった。 


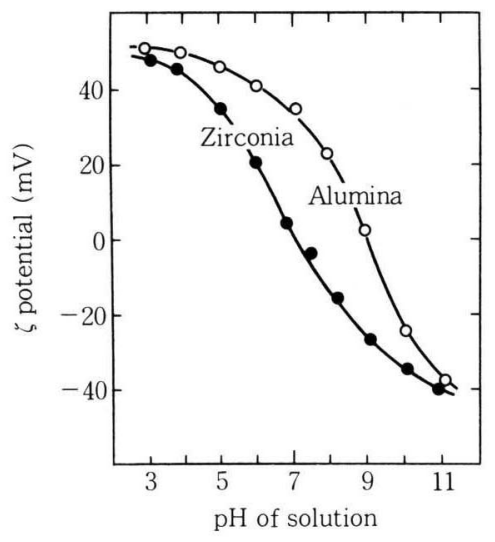

Fig. 3 Zeta potential-pH characteristics of alpha-alumina and monoclinic zirconia fine powder

\section{3 分離実験}

キャリアとする電解質水溶液の調製は, 蒸留水に塩 酸および水酸化力リウムを加え $\mathrm{pH}$ 值を調整し，また 電導度は塩化カリウムを加え調整することにより行っ た。なお, 水溶液を大気中に放置した場合, 空気中の二 酸化炭素と平衡し, $\mathrm{pH}$ 值および電導度を変化させるた め, 調整後十分時間が経過し, これらの值の変化速度が 小さくなった水溶液を使用した。分離装置に, 水溶液 $30.3 \mathrm{ml} / \mathrm{min}$ 流し, 希薄瑟濁液 $0.24 \mathrm{ml} / \mathrm{min}$ 送り込 み, 懸濁液の細流の変形および移動による変位につい て調べ,さらに混合粉体の分離実験を行った。また, 分 離された懸濁液は, スラリーICP発光分析によりアル ミニウムおよびジルコニウム濃度の測定を行った。

\section{4. 実験結果及び考察}

\section{1 希薄懸濁液細流の安定の条件}

混合希薄懸濁液を分離するためには, 懸濁液の流れ が電解質水溶液により搬送される細流となり,この細 流の乱れあるいは変形の大きさが, 電気泳動による 2 種の粉体の移動距離の差に比べて, 小さいことが必要 である。

電極に電圧を加えない場合, 㢡濁液の細流は, 水溶液 の流れのみから力を受け流路を上昇する形となるた め, その安定性は懸濁液と水溶液の密度差に敏感に依 存した。今回の流量条件では, 懸濁液の濃度を350ppm 以上に調製した場合には, 懸濁液は流路を上昇しなか つた。また, 300〜200ppmの範囲では, チューブポン プの僅かな脈動の影響による細流径の変動が増幅され た。濃度が200〜 150ppm以下の懸濁液では, 細流は安
定して上昇した。

電解質水溶液に電圧を加えた場合, 水が電気分解さ れ電極表面に泡が発生する。この泡が流路内を上昇し, 流れを乱す主な原因となった。使用した実験装置で は, 電極の電流密度が $2.5 \mathrm{~mA} / \mathrm{cm}^{2}$ 程度以上になった 場合, 流れの乱れが顕著になり始めた。このため, 水 溶液の電導度を可能な限り低く調整するか, あるいは 電極間に加える電圧を低下させて電流密度を低下させ る必要が明らかとなった。

懸濁液の電導度が水溶液の電導度より大きい場合, 奬濁液の細流は電場と平行方向に引き延ばされた偏平 な形となった(Fig. 4 (a))。逆の場合には, 細流は電 場に垂直な方向に偏平な形に変形し, さらに三日月形 に変形した(Fig. 4(b))。これらの変形は, 電気力線 に治って $\varepsilon E^{2} / 2$ 張力が働くというマックスウェル の応力により定性的に説明できる。ここで, 懸濁液の 細流の断面が円形であるとし, 愻濁液の電導度を $\sigma_{1}$, 水 溶液の電導度を $\sigma_{2}$ とする (Fig. 5)。細流の中心を通る 電気力線上を流れる電流は一定であり, 懸濁液側の電
Anode Cathode
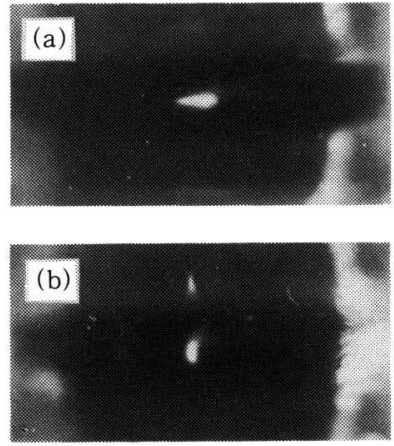

Fig. 4 Photographs of deformed fine stream of the thin suspension in flow of the electrolytic solution by electric field applied perpendicular to the flow, a) electric coductivity of the suspension is higher than the solution, b) conductivity of the solution is higher than the suspension

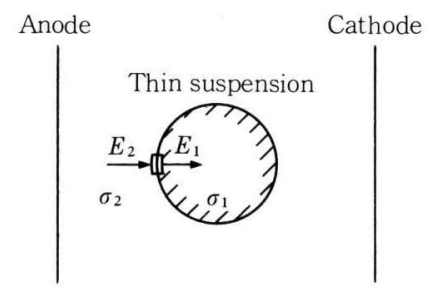

Fig. 5 Model of the fine stream of suspension carried by the flow of electrolytic solution in electric field 
場 $E_{1}$ と水溶液側の電場 $E_{2}$ の間に次の関係が成立す る。

$$
\sigma_{1} E_{1}=\sigma_{2} E_{2}
$$

懸濁液と水溶液の界面には次式で表される力が動く。

$$
\varepsilon\left(E_{1}{ }^{2}-E_{2}{ }^{2}\right) / 2=\varepsilon\left(1-\left(\sigma_{1} / \sigma_{2}\right)^{2}\right) E_{1}{ }^{2} / 2
$$

すなわち, $\sigma_{1}>\sigma_{2}$ の場合, 界面を水溶液側に引く力が働 き, $\sigma_{1}<\sigma_{2}$ の場合には逆向きの力が㗢く。

愁濁液の細流が電場の方向に偏平に変形した場合, 粒子の電気泳動の方向と一致し, 分離のためには好ま しくない。また, 逆に電場と垂直方向に過度に変形し た場合, 電気浸透効果 ${ }^{5)}$ により流路壁近傍と中心部で水 溶液の水平方向の流れが逆向きとなる ${ }^{61}$ ため, 三日月形 に変形した場合にも, 愁濁液が電場の方向に幅を拡大 することになり, 分離のためには必ずしも好ましくな い。

希薄愁濁液の細流が乱れずしかも変形しないために は, 悡濁液と水溶液の密度差を小さくし, 水の電気分解 による発泡を押え, さらに馝濁液と水溶液の電導度を 一致させる必要がある。

\section{2 電場による希薄懸濁液の細流の変位}

幾つかのpH值に調整した水溶液 $(11 \sim 14 \mu \mathrm{S} / \mathrm{cm})$ をキャリアとし，アルミナ希薄㬎濁液( $\mathrm{pH} 5.1,12.2$ $\mu \mathrm{S} / \mathrm{cm}$ ) 及びジルコニア希薄㦟濁液 $(\mathrm{pH} 5.0,12.4$ $\mu \mathrm{S} / \mathrm{cm}$ )の細流に電場を加えたときの, 電極下端から 165mmの位置における㦟濁液の細流の変位をFig. 6に 示す。ここでは, 電圧を加えない時の流れの位置を変 位 0 とし, 陰極の方向への変位を正の值とした。なお, これらの水溶液の条件では, 電極間電圧が40 50V程 度で水の電気分解による発泡がやや多くなるため,こ れ以上の電圧では流れが大きく乱れ測定不能となっ た。

それぞれのpHにおける細流の変位はほぼ電圧に比 例した。これらの変位は, 流路の中央部における水溶 液の電気浸透効果などによる水平方向の流れ之粒子自 身の電気泳動が重なった移動距離を表している。水溶 液の条件が同じである場合, 電気泳動速度は粒子の 電位のみに比例すると考えられるため, 水溶液の水平 方向の流速が電圧にほぼ比例すると考えることができ る。また,アルミナとジルコニア臆濁液に对する変位 量の差は, pH6〜7付近で最も大きくなり, Fig. 2に示 した 電位の差に近似的に対応する。しかしながら， $\mathrm{pH} 5.1$ と比べて二種の粒子の間に十分大きな 差が得られるpH9.3における変位の差がpH5.1の場合
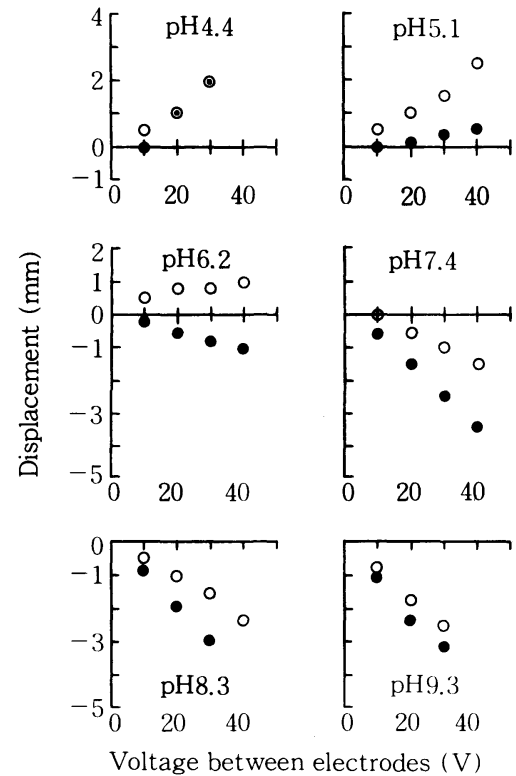

Fig. 6 Displacement of the fine stream of alumina $\bigcirc$ and zirconia suspension due to the applied electric field

の $1 / 2$ 程度に減少している。これは, 電解質の水溶液 が電気分解を受け, 電極近傍の水溶液の $\mathrm{pH}$ 值が大きく 変化し, 流路の中央部においても $\mathrm{pH}$ 值が僅かに変化し た影響と考えられる。

\section{3 混合懸濁液の分離}

水溶液 $(\mathrm{pH} 6.0,13.0 \mu \mathrm{S} / \mathrm{cm})$ をキャリアとし,アル ミナ・ジルコニア混合希薄愁濁液( $\mathrm{pH} 5.0,12.4$ $\mu \mathrm{S} / \mathrm{cm})$ の細流に電場を加えた。このときの揫濁液の 流れの分離状況の例をFig. 7に写真で示す。電極間に 電圧を加えていない場合, 一つの流れとして上昇し, しかも細流の径はほとんど変化していない。20Vの電 圧を加えた場合には明らかに流れが二つに分離し，ま

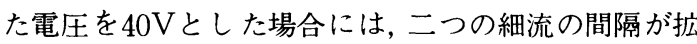
大するが, 細流が少し太くなり, 流れの上部が摇らぐ 様子が観察される。さらに, 電圧を50Vとした場合に は細流の上部が完全に乱れる。

これらの観察結果は, Fig. 6に示したアルミナとジ ルコニアの䄸濁液に対してそれぞれ行った実験と良い 一致を示し，この㦟濁液の条件では愁濁液内のそれぞ れの組成の粒子が互いに独立に泳動できることを示す ものと考えられる。また，電場を加えることにより， 混合愁濁液の細流が二つの流れに完全に分離し，しか も1 $\mathrm{mm}$ 以上の距離が開くことから, Fig. 1に示した回 収装置を用いてそれぞれの成分の愁濁液を回収できる ことが確認できる。 
0V

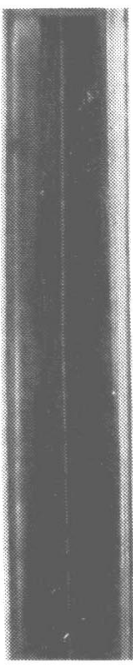

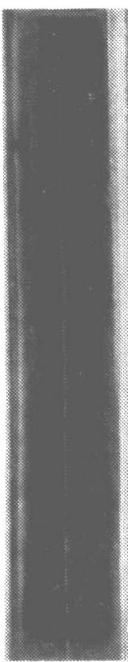

$20 \mathrm{~V}$

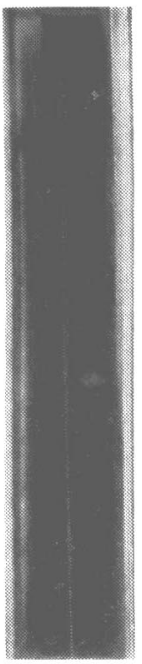

$40 \mathrm{~V}$

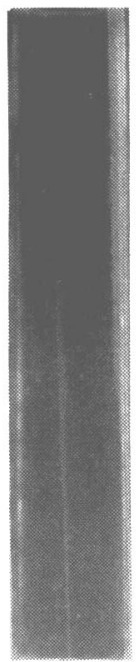

$50 \mathrm{~V}$
Voltage between electrodes $20 \mathrm{~mm}$

Fig. 7 Photographs of separation of the fine stream of mixed suspension of alumina and zirconia under the electric field

幾つかのpH值に調整した水溶液 $(11 \sim 14 \mu \mathrm{S} / \mathrm{cm})$ をキャリアとし，電極間電圧を30Vに固定して，アル ミナ・ジルコニア混合希薄懸濁液( $\mathrm{pH} 5.0,12.4$ $\mu \mathrm{S} / \mathrm{cm}$ )を分離した。このとき得られるアルミナ願 濁液(陰極側細流) あるいはジルコニア懸濁液(陽極側

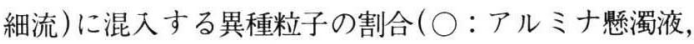
○：ジルコニア馝濁液）と水溶液のpHとの関係をFig. 8に示す。図の縦軸は, 分離後のそれぞれの慜濁液に含 まれる異種粒子と主成分粒子の重量比を, 分離前の榡 濁液中におけるそれらの粒子の重量比で割り規格化し た值を表す。

電気泳動後回収される懸濁液中の粒子濃度は何れも $10 \mathrm{ppm}$ 以下であり, 分離前の総粒子濃度の $1 / 20$ 程度に 薄められたものが回収された。なお，これらの懸濁液 のpH值は調製した水溶液の值から \pm 0.5 以下しかずれ ておらず, 電導度の変化も2割以下であった。

分離後の態濁液が含む異種粒子の量は, 水溶液の $\mathrm{pH}$ 值が 7 付近で最も小さくなり,この值から $\mathrm{pH}$ 值が離 れるに従って異種粒子量が多くなった。この傾向は, Fig. 7に示した二種の䅗濁液の細流の変位差がpH6〜 7で最大になることに対応し，細流の乱れや変形によ る異種粒子の混入の可能性が低下寸るためと解釈され る。なお, 水溶液の $\mathrm{pH}$ 值が7 9 の範囲にある場合に は,アルミナとジルコニアのら電位の符号が異なるた

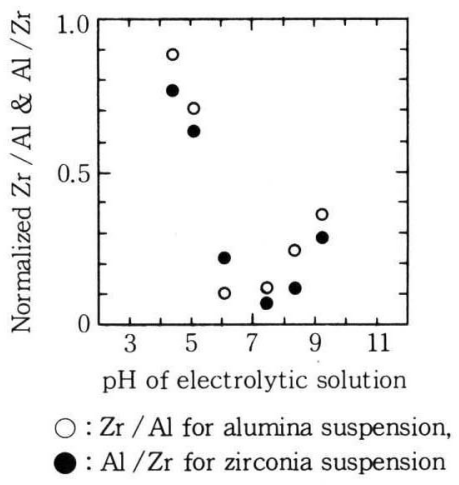

Fig. 8 Variation of weight rario of different particles to principal particles in the separated suspension due to change of $\mathrm{pH}$ of the electrolytic solution, where voltage between electrodes is fixed at $30 \mathrm{~V}$. The vertical axis represents the weight ratio in the separated suspension normalized by the ratio in the original suspension

め, 二つの粒子は電気引力によりへテロ凝集するはず であるが,この領域においても混合懸濁液は十分分離 されている。混合懸濁液の初期の $\mathrm{pH}$ が5.0であるた め,ガラス細管から送り出された細流がすぐにへテロ 凝集城のpHに変化せず, 徐々にそのpHを変え, 異種 粒子同士の間にかなりの距離ができた後, へテロ凝集 城のpH值に達するからであると推察される。

\section{5. むすび}

従来困難とされていたサブミクロンの混合粉体か ら組成に従って粒子を分離する方法の基礎的研究とし て, 電解質水溶液の一様な上昇流中にサブミクロンの アルミナとジルコニアの混合希薄懸濁液の細い流れを 乗せ,この流れに直角に電場を加えることにより, 粒 子を電気泳動させ分離することを試みた。

混合称濁液の細流を安定させるためには, 次の実験 条件を満たす必要があった。

1）愁濁液と水溶液の密度差を小さくする。

2）水の電気分解による発泡を抑制する。

3）惪濁液と水溶液の電導度を一致させる。

粒子どうしがへテロ凝集しないpH5.0で希薄混合懸 濁液を調製し, $\mathrm{pH} 7$ 付近の水溶液をキャリアとして使 用し $10 \mathrm{~V} / \mathrm{cm}$ 電場を加えたとき，それぞれの成分の 懸濁液の細流は $1 \mathrm{~mm}$ 以上分離し, 回収された懸濁液に 混入する異種粒子の濃度を約 $1 / 10$ とすることができ た。 


\section{Nomenclature}

$a$ : radius of particle

$E$ : electric field

$f$ : coefficient of electrophoretic retardation effect

: electrophoretic velocity

$x, y$ : coordinates in a plane perpendicular to the ascent flow (m) $\quad \varepsilon \quad$ : dielectric constant of fluid

$(\mathrm{F} / \mathrm{m})$

$(\mathrm{V} / \mathrm{m}) \quad \eta:$ viscosity coefficient of fluid

$\kappa$ : reciprocal of Debye length

$(\mathrm{Pa} \cdot \mathrm{s})$

$\left(\mathrm{m}^{-1}\right)$

$(-)$

$(\mathrm{m} / \mathrm{s})$

$\sigma$ : conductivity

〈subscript〉

$\left(\mathrm{S} \cdot \mathrm{m}^{-1}\right)$

(mm) 2 : electrolytic solution

\section{References}

1) Mashiko, N., : "Handbook of Separation Science" ed. by M. Senoo, p.48, Kyoritsu Syuppan(1993)

2) Kiso, Y., et al. : ibid., p.158(1993)

3) Henry, D. C. : Proc. Roy. Soc. London, A133, 106 (1931)

4) Wiersema, P. H., A. L. Loeb and J. Th. G.
Overbeek : J. Colloid Interface Sci., 22, 78(1966)

5) Hunter, R. J. : "Zeta Potential in Colloid Science", p.59, Academic Press (1981)

6) Niida, T., M. Yamada, Y. Kouno and Y. Kousaka : J. Soc. Powder Technol., Japan, 23, 422(1986) 